\title{
SISTEM STERILISASI BAKTERI Vibrio harveyi MENGGUNAKAN RADIOISOTOP COBALT-60 UNTUK BUDIDAYA UDANG
}

\author{
Vibrio harveyi BACTERIA STERILIZATION SYSTEM USING COBALT-60 \\ RADIOISOTOP FOR SHRIMP FARMING
}

\author{
Penny Dyah Kusumaningrum, Lolita Thessiana, Niken Financia G. \\ Pusat Pengkajian dan Perekayasaan Teknologi Kelautan danPerikanan \\ Badan Penelitian dan Pengembangan Kelautan Perikanan \\ Jl. Pasir Putih I, Ancol Yimur, Jakarta Utara \\ Email : penny.dyahkusuma@gmail.com
}

Diterima tanggal : 24 Oktober 2016, diterima setelah perbaikan : 25 Januari 2017, disetujui tanggal 31 Januari 2017

\begin{abstract}
ABSTRAK
Vibrinosis adalah penyakit yang disebabkan oleh bakteri Vibrio harveyi. Bakteri ini sebagian besar menyerang larva udang sehingga mengakibatkan resiko kematian yang tinggi. Salah satu upaya menanggulangi serangan bakteri V. harveyi adalah melalui sterilisasi air pada media budidaya. Pemanfaatan iradiasi sinar gamma Cobalt-60 telah banyak dilakukan untuk proses sterilisasi. Keunggulan iradiasi adalah tidak meninggalkan residu, dapat membunuh bekteri secara efektif dan prosesnya mudah dikontrol. Berdasarkan keunggulan tersebut, teknologi ini berpeluang untuk diaplikasikan untuk meningkatkan sterilisasi air yang digunakan pada budidaya udang. Pada penelitian ini digunakan sistem iradiasi menggunakan sumber Co-60 dengan metode statis (5-20 kGy ) dan metode dinamis (23,3 kGy). Hasil penelitian menunjukkan, metode statis dengan dosis $20 \mathrm{kGy}$ mampu mensterilisasi bakteri Vibrio harveyi hingga $100 \%$ setelah 1 jam proses iradiasi. Sementara pada metode sirkulasi, dengan 2 jam proses iradiasi, mampu mensterilisasi bakteri $V$. harveyi hingga 98,75\%.
\end{abstract}

Kata kunci : Vibrio harveyi, irradiasi, Cobalt-60, sterilisasi

\begin{abstract}
Vibrinosis is a disease caused by Vibrio harveyi. These bacteria infect shrimp larval resulting in high mortality. One attempt to overcome V.harveyi attack is hatchery water sterilization. Cobalt-60 gamma ray irradiation has been widely used for sterilization process. Advantages of irradiation sterilization are the process does not leave residue, kill bacteria effectively and easily control the process. Based on some advantages, ths technology is likely to be used as a sterilization method in shrimp farming. The results showed that static irradiation method for 1 hour with $20 \mathrm{kGy}$ doses was capable to sterilize V. harveyi up to $100 \%$. While the circulated irradiation method for 2 hours wasable to kill V. harveyi up to $98.75 \%$.
\end{abstract}

Keywords : Vibrio harveyi, irradiation, Cobalt-60, sterilization

Sistem Sterilisasi Bakteri Vibrio Harveyi Menggunakan Radioisotop Cobalt-60 Untuk Budidaya Udang Penny Dyah Kusumaningrum, Lolita Thessiana, Niken Financia G. 


\section{PENDAHULAN}

Vibrio harveyi adalah bakteri laut Gram Negatif dari Genus Vibrio, mengeluarkan bioluminescens, berbentuk batang, motil dengan flagella polar, bersifat fakultatif anaerob, halofilik dan memiliki metabolisme fermentatif dan respiratori. Bakteri ini bersifat patogen primer dan oportunistik pada hewan laut seperti koral Gorgonia, tiram, udang, lobster, ikan snook, barramundi, turbot, bandeng dan kuda laut (Owens, 2006). Patogenitas $V$. harveyi tergantung pada konsentrasinya pada suatu waktu tertentu. Penyakit yang disebabkan $V$. harveyi adalah lesi mata, gastro-enteritis, vaskulitis dan vibriosis berpendar. Vibriosis berpendar ini merupakan penyebab kematian utama, khususnya pada budidaya udang (Huang et al. 2013). Vibrosis pada budidaya Udang vaname L. vannamei merupakan penyakit yang paling banyak menimbulkan kerugian ekonomi ( $\mathrm{Li}$ dan Xiang 2013). Menurut Flegel dan Sritunyalucksana (2011), kerugian ekonomi penyakit vibrosis pada budidaya udang mencapai 1 milyar USD setiap tahunnya di dunia. Infeksi $V$. harveyi awalnya masuk melalui mulut, membentuk plak, menyebar ke alat gerak kemudian menyebabkan kehilangan fungsi dan degradasi alat gerak. Infeksi Vibrio ini dapat terjadi pada semua fase (telur sampai indukan) dan banyak menyebabkan kasus kematian organisme budidaya sampai $100 \%$ (Ortega dan Diaz 2014). Penyakit yang diakibatkan oleh bakteri ini bersifat sangat akut dan ganas, karena dapat mematikan populasi larva udang dalam waktu 1 sampai 3 hari saja sejak awal dampak (Rukyani, et al., 1992).

Kematian larva akibat infeksi $V$. harveyi tentu dapat berdampak pada produktivitas udang secara keseluruhan. Pada tahun 2009, produksi udang nasional turun menjadi sekitar 299 ribu ton dibandingkan dengan produksi tahun sebelumnya yang lebih dari 400 ribu ton (FAO, 2010). Berbagai upaya yang telah dilakukan seperti disinfeksi tambak secara intensif, mengurangi padat tebar dari $>150$ benur $/ \mathrm{m} 2$ menjadi $60-100$ benur $/ \mathrm{m}^{2}$, mengurangi jumlah petak operasi dalam satu kawasan, mengeringkan total selama satu siklus, atau menggantikan komoditi budidaya dengan ikan nila ataupun bandeng, tidak mampu menghilangkan secara total bakteri patogen dalam tambak (Anonim, 2012).

Salah satu strategi pengelolaan penyakit dalam manajemen budidaya udang, adalah dengan menggunakan benur SPF (Specific Pathogen Free). Benur SPFadalah benur yang bebas dari jenis penyakit tertentu, sehingga memudahkan petambak dalam proses budidaya. Dalam menghasilkan benur SPF, induk maupun benur yang dihasilkan dipelihara dalam air bebas patogen. Sebelum digunakan, air untuk media pertumbuhan udang difilter, diendapkan, disterilisasi dengan disinfektan dan sinar ultraviolet/ozon sehingga didapatkan air yang benar-benar bebas dari patogen. Selain itu, dengan menjaga kualitas air agar tetap sesuai untuk pertumbuhan udang. Penerapan teknologi dengan pengendalian parameter kualitas lingkungan merupakan salah satu faktor yang harus diperhatikan (Adiwidjaya et al. 2001). Salah satu teknologi yang dapat diterapkan untuk tujuan ini adalah teknologi radiasi.

Iradiasi adalah suatu pancaran energi yang berpindah melalui partikel-partikel yang bergerak dalam ruang atau melalui gerak gelombang cahaya. Zat yang dapat memancarkan iradiasi disebut zat radioaktif. Iradiasi yang terjadi akibat peluruhan inti atom dapat berupa partikel alfa, beta, dan sinar gamma (Sinaga, 2000). Sinnar gamma memiliki gelombang elektromagnetik yang bergerak dengan kecepatan hampir seperti kecepatan cahaya, tidak dipengaruhi medan magnet, tidak memiliki muatan, daya ionisasi kecil namun daya tembusnya besar (Ikmalia, 2008). Pada umumnya sinar gamma yang digunakan untuk radiasi adalah Cobalt-60 (Co-60) yang bukan dari hasil fusi melainkan proses penembakan Co-59 dengan neutron selama 1,5 tahun (Morisson, 1989). Co-60 memiliki waktu paruh 5,2 tahun dan meluruh dalam bentuk nikel yang stabil dan tidak mengandung bahan radioaktif (Diehl, 1990).

Penggunaan berbagai dosis sinar gamma telah banyak dilakukan untuk berbagai tujuan antara lain sterilisasi. Penelitian yang pernah dilakukan oleh Natalia dkk (2009) tentang pengaruh iradiasi terhadap bakteri kontaminan makanan menghasilkan bahwa pemberian 
dosis $45 \mathrm{kGy}$ dapat menghilangkan spora $C I$, sporogenes, bakteri Bacillus spp dan Staphylococcus spp. Dosis $25 \mathrm{kGy}$ mampu mensterilisasi bakteri pada makanan hewan (Maha dan Himy, 1983). Iradiasi dengan dosis1,3 dan 5 kGy mampu mereduksi bakteri patogen pada makanan olahan beku (Putri et al. 2015).

Keunggulan iradiasi adalah tidak meninggalkan residu, dapat membunuh bakteri secara efektif dan prosesnya mudah dikontrol. Berdasarkan keunggulan tersebut, teknologi ini berpeluang untuk diaplikasikan untuk meningkatkan kualitas air yang digunakan pada budidaya udang. Namun, untuk dapat diimplementasi secara luas, dibutuhkan sistem iradiasi yang lebih murah, sesuai kebutuhan namun tetap mengutamakan keamanan dan keselamatan. Penelitian ini bertujuan untuk menguji keefektifan teknologi iradiasi menggunakan sumber Co-60 untuk sterilisasi bakteri Vibro harveyi pada media air untuk budidaya udang, dengan metode statis (116 KCurie ) dan metode dinamis (44,5 Curie). Khusus untuk metode dinamis, kecepatan debit aliran dibagi atas debit lambat $(0,06$ liter/detik) dan debit cepat $(0,36$ liter/detik).

\section{BAHAN DAN METODE}

\section{Bahan}

Penelitian ini dilakukan di Pusat Aplikasi Teknologi Isotop dan Radiasi (PATIR) BATAN, Jakarta dan Laboratorium Lingkungan Budidaya Perikanan FPIK, IPB, Bogor pada bulan Maret - Desember 2012. Bahan yang digunakan dalam penelitian ini adalah air laut, larutan nutrient Vibrio sp., inokulan $V$. harveyi, natrium thiosulfat, kaporit, $\mathrm{Pb}$ Shield dan kertas label.

\section{Alat}

Alat yang digunakan dalam penelitian ini adalah timbangan digital, pengukur kualitas air merk YSI, stop watch, gelas ukur, toples plastik, batang pengaduk, aerator, filter cartridge ganda ( gambar 1), batu aerasi, Cobalt -60 aktifitas 44,5 Curie, Cobalt-60 aktifitas 116.000 curie milik IRKA, pipa akrilik modifikasi untuk meradiasi air secara mengalir, selang plastik, instalasi sirkulasi dan MCA (Multi Channel Analyzer). Beberapa alat yang digunakan dalam penelitian ini dapat dilihat pada Gambar 1 .

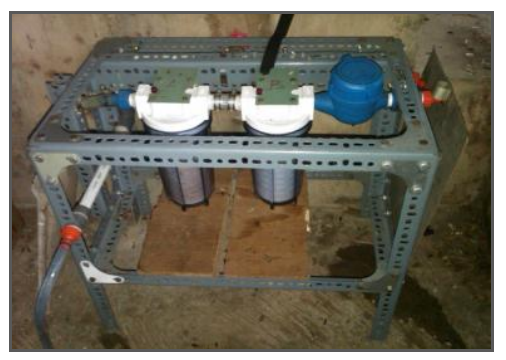

(a)

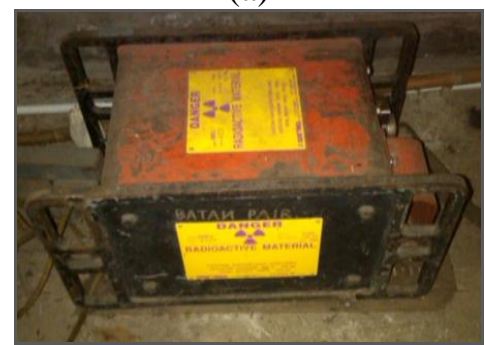

(c)

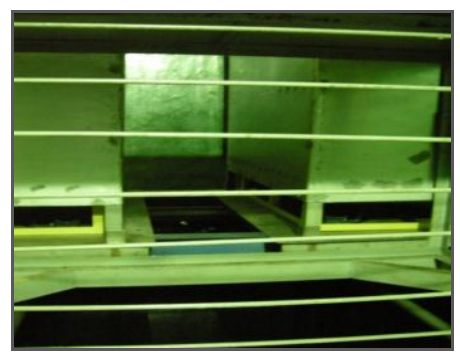

(b).

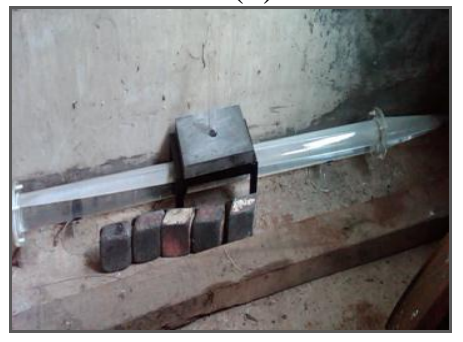

(d).

Gambar 1. Alat yang digunakan dalam penelitian. (a) Filter cartridge, (b) Rak untuk meletakkan barang yang akan diradiasi, (c) Sumber radiasi Cobalt 60, (d) Pipa akrilik dengan $\mathrm{Pb}$ shield.

Sistem Sterilisasi Bakteri Vibrio Harveyi Menggunakan Radioisotop Cobalt-60 Untuk Budidaya Udang Penny Dyah Kusumaningrum, Lolita Thessiana, Niken Financia G. 
Figure 1. Tools used during this study. (a) cartridge filter, (b) Shelf to put irradiated goods, (c) irradiated source Cobalt- 60, (d) Acrylic pipe with Pb shield.

\section{Metode}

Iradiasi sinar gamma pada air laut yang mengandung $V$. harveyi dalam penelitian ini dilakukan dengan metode sirkulasi dan statis.

\section{Metode Statis}

Pada metode statis, sumber radiasi gamma yang digunakan adalah Co-60 dengan aktivitas 116 KCurie. Sumber radiasi Co-60 ini berbentuk batang pipih panjang berwarna biru yang ditempatkan dalam kontainer khusus dan disimpan pada kolam air demineralisasi dengan kedalaman 7 meter. Fasilitas tersebut berada di dalam gedung Iradiator Karet Alam (IRKA) PATIRBATAN. Air laut mengandung $V$. harveyi di dalam 4 wadah dan diradiasi dengan dosis sebesar 5, 10, 15 dan $20 \mathrm{kGy}$ pada laju dosis 8 $\mathrm{kGy} / \mathrm{jam}$. Pada metode statis ini hanya dilakukan satu kali pengambilan data mengingat waktu pengujian yang terbatas mengingat banyak sekali sampel bahan atau produk lain yang harus diuji pada waktu yang hampir bersamaan.

\section{Metode Sirkulasi}

Pada metode sirkulasi, sumber radiasi gamma yang digunakan adalah Cobalt-60 dengan aktivitas 44,5 Curie (Gambar 2). Sumber radiasi Co-60 ini berbentuk batang pendek berwarna biru yang dienkapsulasi baja anti karat dan ditempatkan dalam kontainer khusus yang dapat dipindah-pindahkan (mobile). Air laut yang mengandung Vibrio harveyi dialirkan dalam pipa akrilik secara sirkulasi melewati sumber radiasi dengan debit lambat (0,06 liter/detik) dan debit cepat $(0,36$ liter/detik) dalam interval waktu 0, 30, 60 dan 120 menit. Masing-masing proses sirkulasi baik pada debit cepat dan lambat dilakukan sebanyak dua kali ulangan

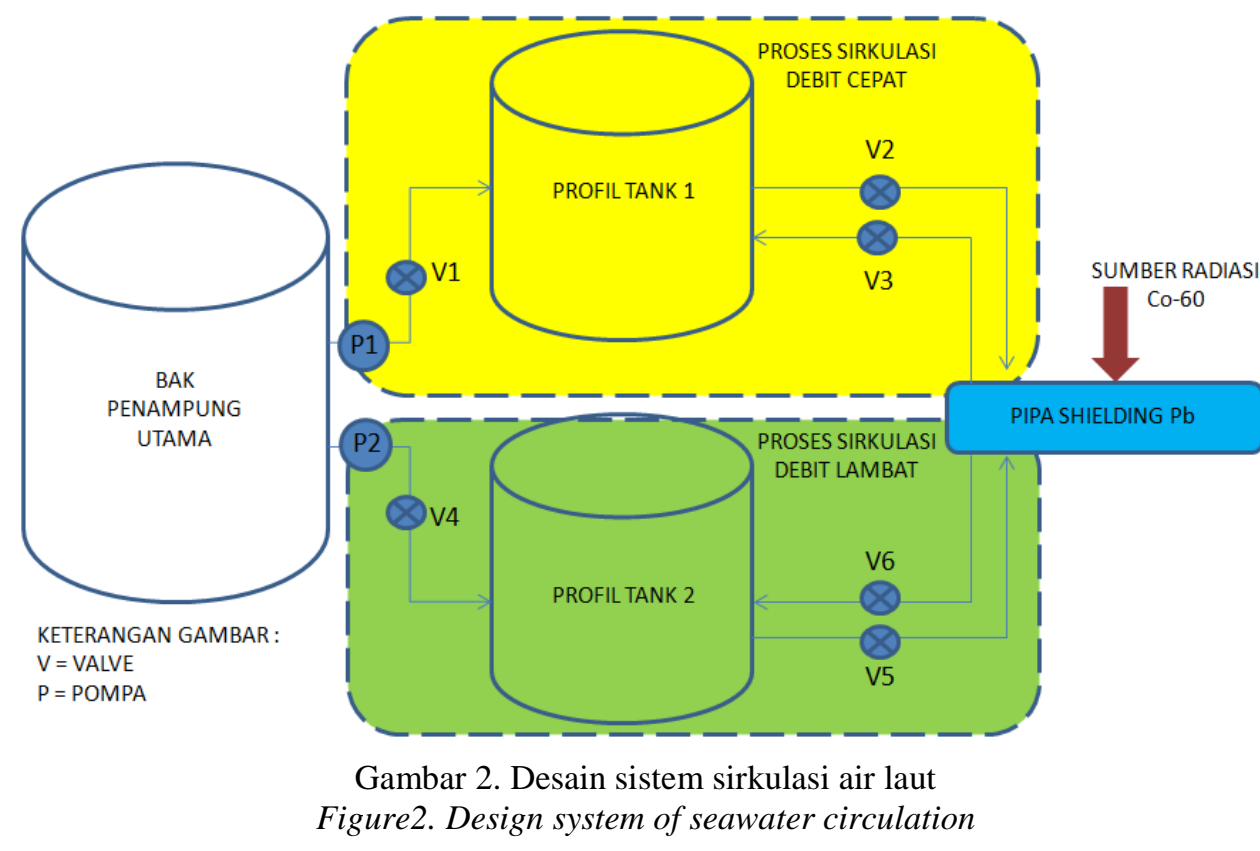

Tahapan penelitian iradiasi sinar gamma pada air laut yang mengandung bakteri Vibrio harveyi adalah sebagai berikut

a. Persiapan Air Laut

Air laut yang digunakan dalam penelitian ini disterilkan menggunakan $150 \mathrm{ppm}$ kaporit dan didiamkan selama 24 jam dalam Bak Penampung Utama (Gambar 2). Selanjutnya kaporit dinetralkan dengan 75 ppm Natrium Tiosulfat, didiamkan selama lebih dari 24 jam dan diaerasi hingga tidak ditemukan residu kaporit. Kemudian air

JURNAL KELAUTAN NASIONAL, Vol. 10, No. 3, Desember 2015, Hal. 125-137 
tersebut disaring menggunakan filter cartridge berdiameter pori $20 \mu \mathrm{m}$ dan dipompa menuju Profil Tank 1 dan Profil Tank 2.

\section{b. Pembiakan kultur bakteri Vibrio harveyi}

$3000 \mathrm{ml}$ larutan nutrien pertumbuhan bakteri Vibrio harveyi dilarutkan dalam air laut, kemudian diaduk rata. $6 \mathrm{ml}$ inokulum bakteri $V$. harveyi ditambahkan ke dalam campuran tersebut dan selanjutnya ditambahkan air laut hingga mencapai volume 75 liter. Campuran tersebut diaerasi selama 24 jam.

c.. Iradiasi Sinar Gamma terhadap Air Laut dengan Metode Statis

Air laut yang mengandung bakteri $V$. harveyi sebanyak 1 liter yang diambil dari Profil Tank 2 ditempatkan dalam toples (Gambar 3). Air diiradiasi dengan sinar gamma dari fasilitas IRKA dengan dosis 5,10, 15 dan $20 \mathrm{kGy}$, dengan laju dosis 8 $\mathrm{kGy} / \mathrm{jam}$. Air yang telah diiradiasi diambil sampelnya untuk selanjutya dilakukan uji keberadaan bakteri vibrio.

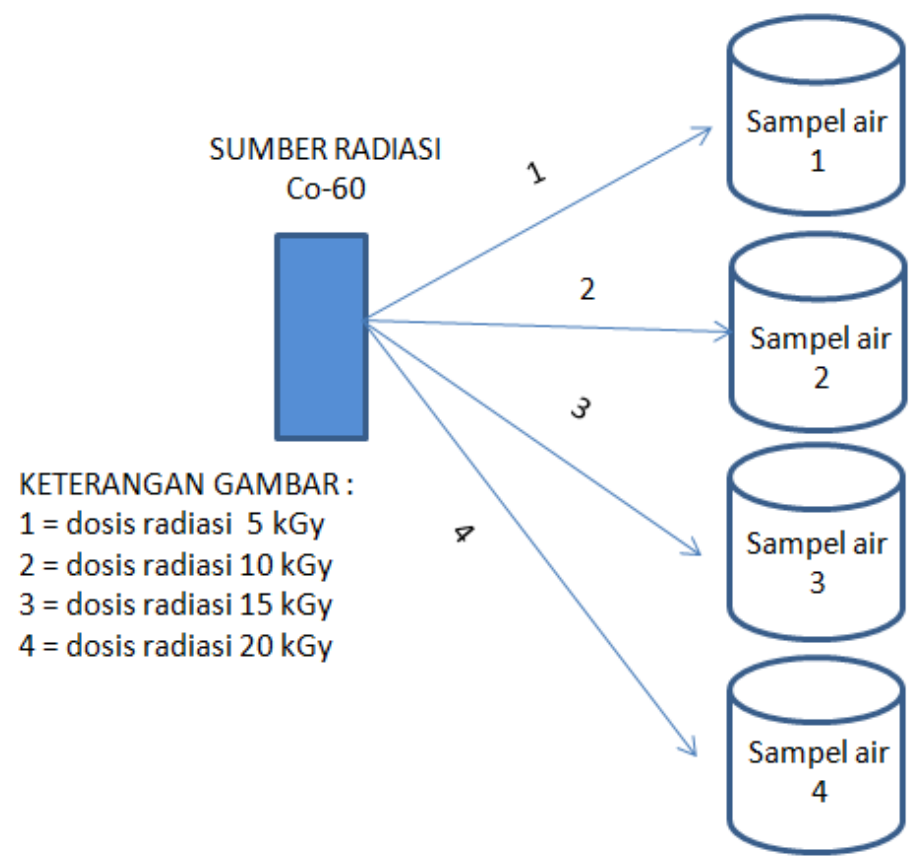

Gambar 3. Radiasi sinar gamma metode statis

Figure 3. Static method of gamma rays radiation

d. Iradiasi Sinar Gamma terhadap Air Laut dengan Metode Sirkulasi

Air laut yang yang mengandung bakteri $V$. harveyi ditempatkan dalam Profil Tank 1 dan Profil Tank 2 dan diaerasi (Gambar 2). Sampel air laut pada masing masing Profil Tank diambil sebanyak 1 liter untuk dijadikan kontrol. Dari Profil Tank 1, air laut dialirkan dengan debit cepat $(0,36$ liter/detik) melalui sumber radiasi dan kembali ke Profil Tank 1. Air laut dialirkan terus menerus selama 30, 60, 90 dan 120 menit. Setiap selang waktu tersebut, air yang sudah diradiasi diambil sampelnya untuk dilakukan pengujian. Dilakukan dua kali pengulangan pada debit cepat ini.

Setelah proses sirkulasi dengan debit cepat selesai, dilanjutkan dengan proses sirkulasi debit lambat (0,06 liter/detik). Sama halnya dengan proses pada debit cepat, sampel air laut diambil dari Profil tank 2 sebanyak 1 liter sebagai kontrol. Dari Profil Tank 2, air laut dialirkan dengan lambat melalui sumber radiasi dan 
kembali ke Profil Tank 2. Air laut dialirkan terus menerus selama 30, 60, 90 dan 120 menit. Setiap selang waktu tersebut, air yang sudah diradiasi diambil sampelnya untuk dilakukan pengujian Seperti halnya debit cepat, percobaan pada debit ini dilakukan dua kali pengulangan.

e. Pengujian

Sampel hasil radiasi dengan metode statis dan sirkulasi dilakukan pengujian sisa residu radiaoktif menggunakan MCA (Multi Channel Analyzer). Analisa bakteri total dilakukan dengan media SWC (Sea Water Count) dan analisa bakteri $V$. harveyi dengan media TCBS (Thiosulfate Citrate Bile Salt) Agar.

f. Pengukuran parameter kualitas air.

Parameter yang diukur meliputi parameter fisika (konduktivitas dan suhu) dan parameter kimia ( $\mathrm{pH}, \mathrm{DO}$ dan salinitas). Pengambilan sampel air untuk diukur parameternya ini dilakukan setiap 30 menit, sebelum dan sesudah dilakukan radiasi pada sistem sirkulasi (0-120 menit). Pengukuran ini untuk mengetahui sejauh mana pengaruh iradiasi terhadap perubahan kualitas sebagai media tumbuhnya bakteri $V$. Harveyi.

\section{HASIL DAN PEMBAHASAN}

\section{Iradiasi Sinar Gamma Cobalt-60 Dengan Metode Statis}

Hasil pengujian kuantitatif bakteri $V$. harveyi dengan iradiasi sinar gamma Cobalt-60 selama 1 jam dapat dilihat pada Tabel 1 berikut ini:

Tabel 1. Jumlah Bakteri $V$. harveyi dengan perlakuan berbagai dosis radiasi Co-60 pada Metode Statis

Table 1. The amount of $V$. harveyi bacteria after irradiated with various doses of Co-60 on Static Methods

\begin{tabular}{cc}
\hline \hline Dosis Radiasi (kGy) & Total bakteri $(\mathrm{cfu} / \mathrm{ml})$ \\
\hline 0 & $1.26 \times 10^{8}$ \\
5 & $1.6 \times 10^{4}$ \\
10 & $1.5 \times 10^{4}$ \\
15 & $1.0 \times 10^{4}$ \\
20 & 0 \\
\hline
\end{tabular}

Berdasarkan Tabel 1, jumlah bakteri yang bertahan hidup semakin menurun seiring dengan penambahan dosis radiasi yang diberikan. Pemberian dosis radiasi terendah, yaitu sebesar 5 kGy mampu menghilangkan bakteri hingga $99,987 \%$. Total bakteri berkurang dari $1.26 \times 10^{8} \mathrm{cfu} / \mathrm{ml}$ menjadi 1.6 $\mathrm{x} 10^{4} \mathrm{cfu} / \mathrm{ml}$. Proses sterilisasi air laut terjadi saat pemberian dosis radiasi sebesar $20 \mathrm{kGy}$ yang menyebabkan kematian bakteri mencapai $100 \%$. Namun untuk mengetahui $\mathrm{D}_{10}$ yaitu dosis yang menyebabkan kematian bakteri mencapai 90\%, perlu dilakukan pengujian lebih lanjut tentang iradiasi air laut dengan metode statis menggunakan dosis radiasi $0-5 \mathrm{kGy}$.

Semakin besar dosis radiasi yang diberikan, semakin efektif radiasi tersebut dalam membunuh koloni bakteri. Kume (2005) menyatakan bahwa radiasi sinar Gamma memiliki efektivitas yang berbeda dalam membunuh mikroba sesuai besaran dosis yang diberikan. Semakin besar dosis yang diberikan, energi mematikan mikroba juga semakin besar (Gambar 4). 


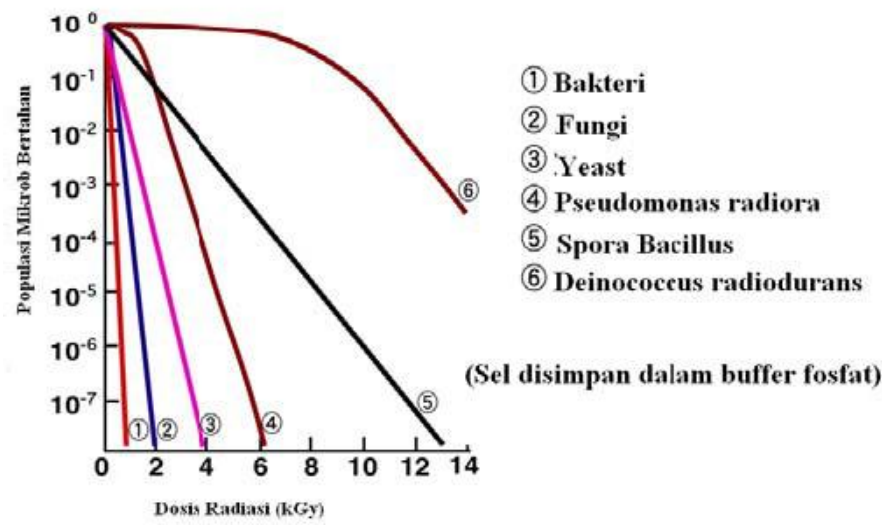

Gambar 4. Efektivitas berbagai dosis radiasi sinar Gamma untuk membunuh mikroba (Kume, 2005).

Figure 4. Effectiveness of gamma radiation various doses to kill microbes (Kume, 2005)

Berdasarkan Gambar 4, terlihat bahwa dengan dosis kurang dari $2 \mathrm{kGy}$, sebenarnya bakteri sudah dapat disterilkan melalui teknologi iradiasi. Hasil dalam penelitian ini menunjukkan bahwa dengan dosis radiasi 5 $\mathrm{kGy}$, terjadi penurunan total bakteri sebesar $99,987 \%$. Pemberian dosis radiasi sebesar 10$15 \mathrm{kGy}$ memberikan hasil yang hampir sama dengan dosis $5 \mathrm{kGy}$, namun ketika dosis dinaikkan menjadi $20 \mathrm{kGy}$, tingkat kematian bakteri mencapai $100 \%$ dan air dalam keadaan steril.

Kajian yang dilakukan Gelli et al. (2001), bahwa dosis radiasi 1,5 kGy telah cukup mematikan $10^{10} \mathrm{cfu} / \mathrm{ml}$ suspensi Vibrio spp. Perbedaan ini mungkin disebabkan oleh turbiditas air laut yang digunakan dalam penelitian ini lebih tinggi dibandingkan medium kultur murni Vibrio spp. sehingga penetrasi sinar gamma ke dalam air laut tidak optimum akibat terabsorbsi oleh partikelpartikel dalam air laut tersebut

Menurut Putri, et al. (2015), pengaruh iradiasi yang terjadi pada organisme hidup, terkait dengan perubahan kimia yang tergantung oleh faktor fisik dan organisme itu sendiri. Salah satu paremeter fisik adalah besaran dosis. Pada prinsipnya jika suatu materi terkena iradiasi sinar gamma, akan menimbulkan eksitasi, ionisasi dan perubahan kimia. Jika perubahan kimia terjadi pada sel hidup, akan menghambat proses sintesis DNA yang menyebabkan proses pembelahan sel terganggu. Ketika radiasi terjadi pada organisme, akan terjadi tumbukan antara energi radiasi dengan elektron sel penyusun organisme dan menyebabkan terputusnya ikatan rantai DNA. Akibatnya hal ini mempengaruhi sel untuk bereproduksi atau bertahan.

Iradiasi pada organisme dapat menimbulkan perubahan dan hilangnya basa nitrogen, pemutusan ikatan hidrogen, pemutusan rantai gula fosfat dari masing masing polinukleotida dari DNA (single strand break), pemutusan rantai yang berdekatan pada kedua polinukleotida dari DNA (double strand break) dan terbentuk ikatan silang intermolekuler (base damage). Kebanyakan organisme mampu memperbaiki kerusakan single strand break. Beberapa literatur menyebutkan bahwa organisme yang sensitif tidak dapat memperbaiki double strand breaks, sedangkan organisme yang memiliki resistensi lebih tinggi mempunyai kemampuan untuk memperbaiki double stand breaks. Hasil perbaikan atau penyusunan kembali DNA tersebut dapat sama atau berbeda dengan semula. Penyusunan ulang yang berbeda dapat berakibat pada kematian sel, mutasi atau transformasi (Tetriana dan Sugoro, 2007)

Berdasarkan alasan tersebut di atas maka jika energi iradiasi sinar Gamma mengenai koloni bakteri, kemungkinan yang terjadi adalah bakteri tersebut terbunuh, tidak aktif atau terhambat pertumbuhannya (Darjanto, 1995). 
Jika masih ada bakteri yang hidup kemungkinan disebabkan oleh perbedaan atau perubahan sifat kepekaan/daya tahan terhadap radiasi.

Energi iradiasi sinar gamma sebesar 5-15 kGy pada $V$. harveyi dalam percobaan ini mampu menghambat proses sintesis DNA yang menyebabkan proses pembelahan sel bakteri terganggu. Ketika radiasi terjadi pada bakteri, akan terjadi tumbukan antara energi radiasi dengan elektron sel penyusun bakteri dan menyebabkan terputusnya ikatan rantai DNA. Akibatnya sebagian besar koloni $V$. harveyi mati. Ketika dosis radiasi dinaikkan sebesar $20 \mathrm{kGy}$ bakteri menjadi kehilangan resistensi, tidak dapat memperbaiki kerusakan baik di single strand break maupun double strand break, akibatnya menimbulkan kematian sel penyusunnya.

\section{Iradiasi Sinar Gamma Cobalt-60 Dengan Metode Sirkulasi}

Hasil iradiasi sinar gamma pada air laut dengan metode sirkulasi dengan debit cepat $(0,36$ liter/detik) dan debit lambat $(0,06$ liter/detik) dapat dilihat pada Tabel 2 dan 3. Perbedaan kecepatan ini bermaksud untuk mengetahui sejauh mana pengaruh aliran air yang melewati sumber radiasi sinar gamma Co-60 mampu membunuh bakteri $V$. harvey. Dilakukan sebanyak dua kali pengulangan pada masing-masing metode sirkulasi ini untuk disebabkan karena mempertimbangkan ketersediaan bakteri $V$ harveyi selama penelitian ini dilaksanakan.

Tabel 2. Jumlah bakteri $V$. harveyi setelah diradiasi Co-60 dalam beberapa interval waktu pada metode sirkulasi berdebit 0,36 liter/detik.

Table 2. Amount of $V$. harveyi bacteria after irradiated with Co-60 in some time interval during circulation method with water discharge 0.36 liters / sec.

\begin{tabular}{cccc}
\hline \hline $\begin{array}{c}\text { Waktu Iradiasi } \\
(\text { menit })\end{array}$ & $\begin{array}{c}\text { Total Bakteri Percobaan 1 } \\
(\mathrm{cfu} / \mathrm{ml})\end{array}$ & $\begin{array}{c}\text { Total Bakteri Percobaan 2 } \\
(\mathrm{cfu} / \mathrm{ml})\end{array}$ & $\begin{array}{c}\text { Total Bakteri Rata- } \\
\text { rata }(\mathrm{cfu} / \mathrm{ml})\end{array}$ \\
\hline 0 & $2,14 \times 10^{8}$ & $2,78 \times 10^{8}$ & $2.46 \times 10^{8}$ \\
\hline 30 & TBUD & TBUD & TBUD \\
\hline 60 & TBUD & TBUD & TBUD \\
\hline 90 & TBUD & TBUD & TBUD \\
\hline 120 & TBUD & TBUD & TBUD \\
\hline
\end{tabular}

Keterangan:

TBUD: Tidak Bisa Untuk Dihitung

Tabel 3. Jumlah bakteri $V$. harveyi setelah diradiasi Co-60 dalam beberapa interval waktu pada metode sirkulasi berdebit 0,06 liter/detik.

Table 3. Amount of $V$. harveyi bacteria after irradiated with Co-60 in some time interval during circulation method with water discharge 0,06 liters / sec.

\begin{tabular}{cccc}
\hline \hline $\begin{array}{c}\text { Waktu Iradiasi } \\
(\text { menit })\end{array}$ & $\begin{array}{c}\text { Total Bakteri Percobaan 1 } \\
(\mathrm{cfu} / \mathrm{ml})\end{array}$ & $\begin{array}{c}\text { Total Bakteri Percobaan } \\
2(\mathrm{cfu} / \mathrm{ml})\end{array}$ & $\begin{array}{c}\text { Total Bakteri Rata- } \\
\text { rata }(\mathrm{cfu} / \mathrm{ml})\end{array}$ \\
\hline 0 & $1,19 \times 10^{8}$ & $1,33 \times 10^{8}$ & $1.26 \times 10^{8}$ \\
30 & TBUD & TBUD & TBUD \\
60 & TBUD & TBUD & TBUD \\
90 & TBUD & TBUD & TBUD \\
120 & $1,47 \times 10^{8}$ & $1,69 \times 10^{8}$ & $1.58 \times 10^{6}$ \\
\hline
\end{tabular}

Keterangan:

JURNAL KELAUTAN NASIONAL, Vol. 10, No. 3, Desember 2015, Hal. 125-137 
TBUD: Tidak Bisa Untuk Dihitung

Hasil iradiasi dengan debit cepat maupun lambat menunjukkan bahwa masih terdapat bakteri $V$. harveyi di dalam air laut yang telah diiradiasi hingga 120 menit. Beberapa hasil pengujian tidak bisa dihitung karena koloni $V$. harveyi tumbuh terlalu banyak, yaitu lebih dari setengah penampang cawan petri.

Kecepatan debit aliran air mempengaruhi proses iradiasi pada bakteri. Pada aliran cepat, waktu terpapar bakteri oleh iradiasi menjadi cukup singkat. Bakteri menjadi sangat resisten terhadap energi radiasi dan tidak ada kerusakan pada sel penyusun. Dalam proses ini tidak mengakibatkan kematian bahkan sel penyusun dapat membelah diri sangat cepat. Akibatnya bakteri tumbuh dengan pesat. Pada menit ke 30 sampai 120, jumlah koloni sangat banyak dan tidak dapat dihitung.

Hal yang berbeda ditunjukkan ketika kecepatan aliran debit diturunkan menjadi 0,06 liter/detik. Dengan debit lebih lambat, jumlah sel menurun seiring dengan semakin lamanya air tersebut berada dalam sistem sirkulasi. Hasil pengujian menunjukkan bahwa terjadi penurunan total bakteri sebanyak 98,75 \% dibandingkan kontrol setelah proses iradiasi selama 120 menit. Namun periode iradiasi 30 menit hingga 90 menit tidak menunjukkan data kuantitatif karena bakteri memenuhi lebih dari setengah dari cawan petri sehingga tidak dapat dihitung jumlahnya. Oleh karena itu, nilai $\mathrm{D}_{10}$ akan didapat pada waktu iradiasi antara $30-90$ menit. Hal ini disebabkan oleh semakin lamanya air laut dan bakteri yang terkandung di dalamnya terpapar radiasi sinar gamma. Silinder and Ozer (2009) menyebutkan bahwa lama radiasi merupakan faktor yang mempengaruhi efek radiasi terhadap sel bakteri. Semakin lama sel bakteri terpapar radiasi, semakin besar efek radiasi terhadap sel tersebut. Radiasi sinar gamma menyebabkan kerusakan struktur DNA sel bakteri sehingga menyebabkan kematian bakteri (Berk dan Özer, 1999).

\section{Pengujian Kualitas Air}

Kondisi kualitas air selama penelitian dapat dilihat pada Gambar 4. Hasil pengukuran beberapa parameter kualitas air, menunjukkan bahwa salinitas, $\mathrm{pH}$, konduktivitas air sebelum dan setelah diiradiasi dalam empat periode waktu yang berbeda tidak menunjukkan perubahan, yaitu salinitas berkisar 2,9\%, pH 7 dan konduktivitas pada $44 \mathrm{~ms} / \mathrm{cm}$.

\begin{tabular}{cccc}
\hline \hline $\begin{array}{c}\text { Waktu Iradiasi } \\
(\text { menit })\end{array}$ & $\begin{array}{c}\text { Total Bakteri Percobaan 1 } \\
(\mathrm{cfu} / \mathrm{ml})\end{array}$ & $\begin{array}{c}\text { Total Bakteri Percobaan } \\
2(\mathrm{cfu} / \mathrm{ml})\end{array}$ & $\begin{array}{c}\text { Total Bakteri Rata- } \\
\text { rata }(\mathrm{cfu} / \mathrm{ml})\end{array}$ \\
\hline 0 & $1,19 \times 10^{8}$ & $1,33 \times 10^{8}$ & $1.26 \times 10^{8}$ \\
30 & TBUD & TBUD & TBUD \\
60 & TBUD & TBUD & TBUD \\
90 & TBUD & TBUD & TBUD \\
120 & $1,47 \times 10^{8}$ & $1,69 \times 10^{8}$ & $1.58 \times 10^{6}$ \\
\hline
\end{tabular}

Sistem Sterilisasi Bakteri Vibrio Harveyi Menggunakan Radioisotop Cobalt-60 Untuk Budidaya Udang Penny Dyah Kusumaningrum, Lolita Thessiana, Niken Financia G. 


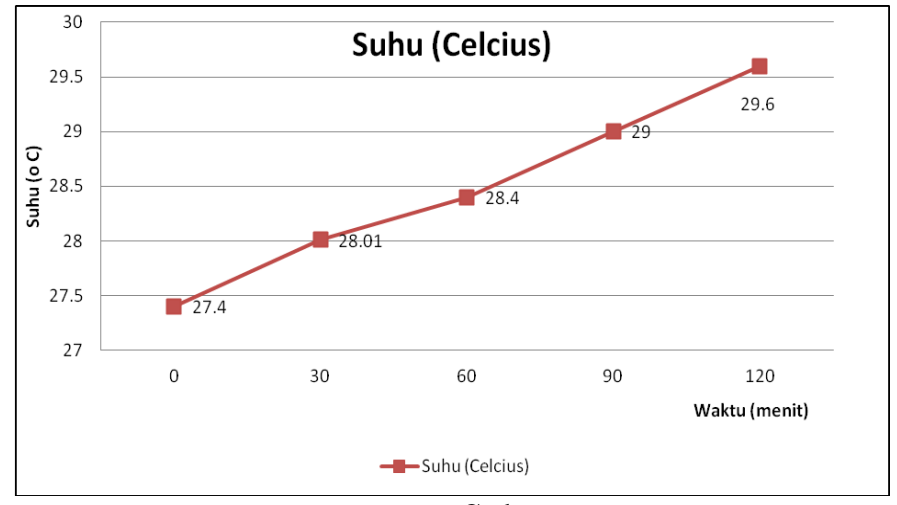

a. Suhu

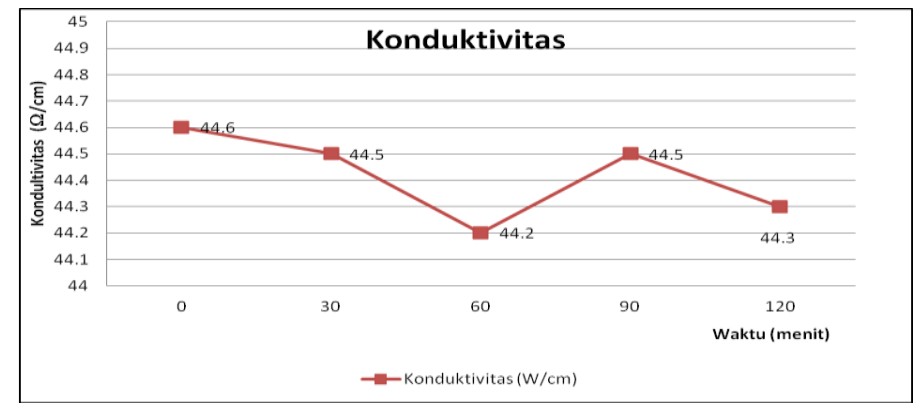

b. Konduktivitas

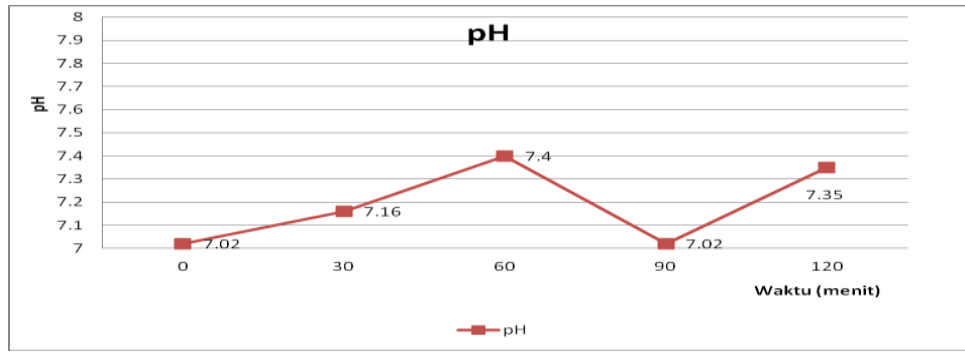

c. $\mathrm{pH}$

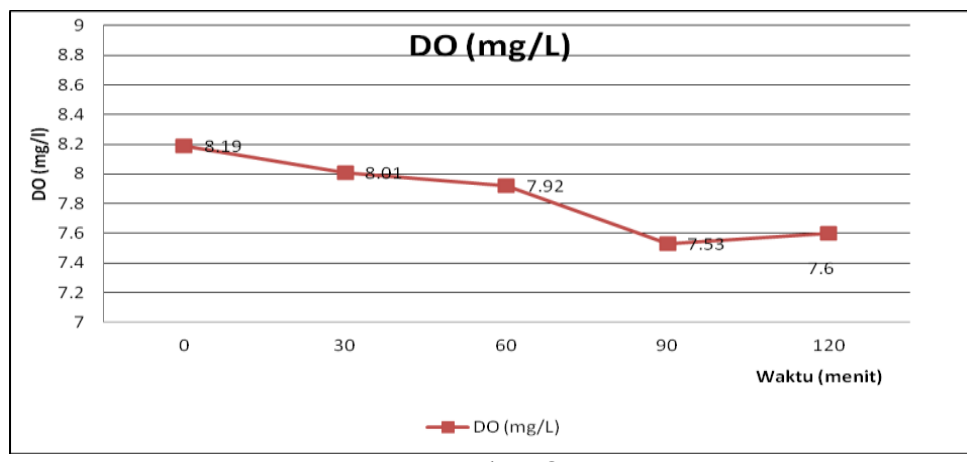

d. DO 


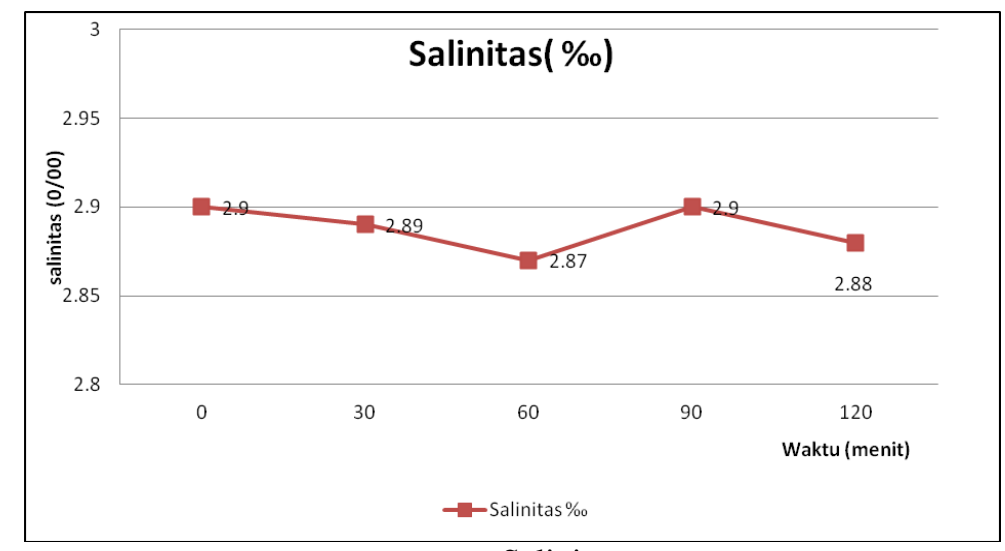

e. Salinitas

Gambar 5. Parameter kualitas air rata-rata selama penelitian; (a) Suhu (b) Konduktivitas (c) pH (d) DO (e) Salinitas

Figure 5. The average of water quality parameters during the study, (a) Temperature (b) Conductivity (c) $\mathrm{pH}(\mathrm{c}) \mathrm{DO}(\mathrm{e})$ Salinity

Parameter yang mengalami perubahan adalah nilai oksigen terlarut dalam air. Penurunan nilai oksigen terlarut terbesar terjadi saat iradiasi selama 90 menit dengan kadar oksigen terlarut sebesar $7,5 \mathrm{mg} / \mathrm{ml}$, bila dibandingkan dengan kontrol maka terjadi penurunan nilai DO sebanyak $8 \%$. Meskipun terjadi penurunan nilai DO, namun kadar oksigen terlarut dalam air masih sesuai untuk kegiatan budidaya, yaitu > $3 \mathrm{mg} / \mathrm{L}$. Temperatur air selama percobaan mengalami peningkatan secara perlahan sejalan dengan periode iradiasi, pada periode 120 menit terjadi peningkatan suhu sebesar $2^{\circ} \mathrm{C}$ bila dibandingkan dengan suhu kontrol. Peningkatan suhu air terjadi karena adanya kontak antara air dengan panas dari proses iradiasi dan pompa sirkulasi. Berdasarkan hasil pengukuran tersebut terbukti bahwa iradiasi sinar gamma Co-60 tidak berpengaruh terhadap kuliatas air.

\section{KESIMPULAN DAN SARAN}

\section{Kesimpulan}

Iradiasi sinar gamma Co-60 sistem statis memiliki $\mathrm{D}_{10}$ pada dosis $5 \mathrm{kGy}$. Pada dosis tersebut, terjadi tingkat penurunan bakteri $\mathrm{V}$. harveyi sebanyak $99,99 \%$ setelah diiradiasi selama 1 jam. Jumlah koloni bakteri berkurang dari $1.26 \times 10^{8} \mathrm{cfu} / \mathrm{ml}$ menjadi 1.6 $\mathrm{x} 10^{4} \mathrm{cfu} / \mathrm{ml}$. Proses sterilisasi air laut terjadi saat pemberian dosis radiasi sebesar $20 \mathrm{kGy}$ dimana kematian bakteri mencapai $100 \%$. Iradiasi sinar gamma Co-60 sistem dinamis dengan debit 0,36 liter/jam tidak mampu mensterilisasi air laut dari $V$. harveyii meskipun setelah dialirkan sampai 2 jam. Hal ini disebabkan, waktu terpapar bakteri oleh iradiasi menjadi cukup singkat. Bakteri menjadi sangat resisten terhadap energi radiasi dan tidak ada kerusakan pada sel penyusun. Dalam proses ini tidak mengakibatkan kematian bahkan sel penyusun dapat membelah diri sangat cepat. Akibatnya bakteri tumbuh dengan pesat. Setelah 2 jam proses iradiasi koloni sangat banyak dan tidak dapat dihitung. Ketika kecepatan aliran debit diturunkan menjadi 0,06 liter/detik. terjadi penurunan konsentrasi bakteri sebanyak 98,75 $\%$ setelah proses iradiasi selama 2 jam. Nilai $\mathrm{D}_{10}$ akan didapat pada waktu iradiasi antara 30 - 90 menit. Hal ini membuktikan bahwa kecepatan aliran air mempenaruhi proses iradiasi bakteri $V$. harveyi. Dari dua metode tersebut, iradiasi sinar gamma Co-60 dengan sistem statis $20 \mathrm{kGy}$ paling baik hasilnya, mampu membunuh bakteri $V$. harveyii sebanyak hingga $100 \%$. Hasil pengujian secara umum menunjukkan bahwa jumlah bakteri yang bertahan hidup semakin menurun 
seiring dengan penambahan dosis radiasi yang diberikan, kecuali pada sistem sirkulasi debit cepat. Iradiasi tidak mempengaruhi kualitas perairan. Nilai suhu, salinitas, $\mathrm{DO}, \mathrm{pH}$ dan konduktivitas tidak mengalami perubahan setelah proses iradiasi dilakukan.

\section{Saran}

Pemberian dosis radiasi terendah pada sistem statis, yaitu sebesar 5 kGy mampu menghilangkan bakteri hingga 99,99\%. Proses sterilisasi air laut terjadi saat pemberian dosis radiasi sebesar 20 kGy dimana kematian bakteri mencapai $100 \%$. Untuk mengetahui $D_{10}$ yaitu dosis dimana kematian bakteri mencapai $90 \%$, perlu dilakukan pengujian iradiasi air laut dengan metode statis menggunakan dosis radiasi $0-5$ kGy.

\section{UCAPAN TERIMA KASIH}

Penulis menyampaikan terima kasih sebesarbesarnya kepada Pusat Aplikasi Teknologi Isotop dan Radiasi (PATIR) BATAN, Jakarta dan Laboratorium Lingkungan Budidaya Perikanan FPIK, IPB, Bogor yang telah membantu dan menyediakan fasilitas terselerenggaranya kegiatan penelitian ini.

\section{DAFTAR PUSTAKA}

Adiwidjaya, D., Coco K., Supito, (2001). Teknis Operasional Budidaya Udang Ramah Lingkungan. Departemen Kelautan dan Perikanan. Direktorat Jenderal Perikanan Budidaya. Balai Besar Pengembangan Budidaya Air Payau. Jepara. 29 halaman.

Anonim. (2012). Bambang Widigdo : Tantangan dan Strategi Budidaya Udang (1 April 2007)

http://www.trobos.com/show article.php?ri $\underline{\mathrm{d}=22 \& \text { aid }=2846} \quad$ (Tanggal akses: 20 Oktober 2014).

Boyd, C.E., (2008). Chlorine Effective Disinfectant in Aquaculture. Global Aquaculture Advocate. Ed. November Desember 2008. P. 52-53.

Darjanto, L. D. (1995). Pengaruh Laju Dosis dan Dosis Iradiasi Gamma Cobalt-60 terhadap Jumlah Sel dan Harga D10 Salmonella spp pada Media NA dan BHI Agar [skripsi]. Jurusan Biologi. Fakultas Matematika dan
Ilmu Pengetahuan Alam. Universitas Padjajaran. Bandung.

Diehl, (1990), Safety of Irradiated Foods., New York, Marcel Dekker Inc.

Flegel TW, Sritunyalucksana K. (2011). Shrimp Molecular Responses to Viral Pathogens. Marine Biotechnology 13:587-607.

Gelli,D.S., N. del Mastro, I. Rodrigues de Moraes, M. Jakabi. (2001). Irradiation to Control Vibrio Infection From Consumption of Raw Seafood and Fresh Produce. IAEATECDOC-1213. ISSN 1011-4289. Austria.

Huang HH, Liu XL, Xiang JH, Wang P. (2015). Immune response of Litopenaeus vannamei after infection with Vibrio harveyi. Aquaculture 406-407:115-120

Ikmalia. (2008) Analisa Profil Protein Hasil Isolate Escherichia Coli S1 Hasil Radiasi Sinar Gamma, Skripsi, Universitas Islam Negeri Syarif Hidayatullah, Jakarta.

Kume, T. (2005). Radiation Sterilization of Carrier. FNCA Biofertilizer Project Technical Meeting on Sterilization of Carrier by Irradiation. Tokyo.

Li F, Xiang J. (2013). Recent advances in researches on the innate immunity of shrimp in China. Developmental and Comparative Immunology 39:11-26.

Maha, M, Hilmy N. (1983), Pengawetan Makanan Dengan Iradiasi, Risalah Seminar Nasional. Jakarta, 6-8 Juni 1983.

Natalia, Lili. Priadi A. Irawati Z. (2009). Pengaruh Iradiasi Terhadap Daya Hidup Bakteri Kontaminan Dalam Makanan, Jurnal Ilmu Ternak dan Veteriner (JITV) 14(1); 58-65, Pusat Penelitiandan Pengembangan Peternakan.

Carlos O. Lomelí-Ortega, Sergio F. Martínez-Díaz. (2014). Phage therapy against Vibrio parahaemolyticus infection in the white leg shrimp (Litopenaeus vannamei) larvae. Aquaculture 434:208-211.

Owens, L., Busico-Salcedo., Nancy. (2006). Vibrio harveyi: Pretty Problems in Paradise (Chapter 19). In Thompson, Fabiano; Austin, Brian; Swings, Jean. The Biology of Vibrios. ASM Press.

Putri, Fabriyana N.A., Wardani, Kirana A., Harsojo. (2015). Aplikasi Teknologi Iradiasi Gamma dan Penyimpanan Beku pada Seafood. Jurnal Pangan dan Agroindustri Vol. 3 No. 2, p 345-352 April 2015.

Rukyani, A., Taufik, P., dan Taukhid. (1992). Penyakit Kunang-Kunang (Luminescence vibriosis) di Hatchery Udang Windu dan Cara Penanggulangan Penyakit Benur di hatchery Udang. Jurnal Litbang Pertanian. 
2:1-17.

Silinder, M., A. Yekta Ozer. (2009). Sterilization Methods and the Comparison of E-Beam Sterilization with Gamma Radiation Sterilization. FABAD J. Pharm. Sci., $34: 43-53$.

Sinaga R. (2000). Pemanfaatan Teknologi Iradiasi dalam Pengawetan Makanan. Prosiding Seminar Ilmiah Nasional dalam Rangka Lustrum IV Fakultas Biologi Universitas Gadjah Mada, Penerbit MEDIKA, Yogyakarta, 2-7.

Tetriana D, Sugoro I. (2007). Aplikasi Teknik Nuklir dalam Bidang Vaksin. Jurnal Alara Vol. 1. PTKMR- BATAN, PATIR

BATAN Pasar Jumat, Jakarta.

Sistem Sterilisasi Bakteri Vibrio Harveyi Menggunakan Radioisotop Cobalt-60 Untuk Budidaya Udang Penny Dyah Kusumaningrum, Lolita Thessiana, Niken Financia G. 